\title{
Pengaruh Pengungkit Keuangan dan Profitabilitas Terhadap Perataan Laba Pada Indeks IDX Quality 30 Non Bank Periode 2015-2019
}

Financial Leverage and Profitability effect in IDXQ3 profit

Fitri Apriani Maudinah

Program Studi Manajemen, Institut Pertanian Bogor

Bogor, Indonesia

E-Mail: fitriapriani0804@gmail.com

Ali Mutasowifin

Program Studi Manajemen, Institut Pertanian Bogor

Bogor, Indonesia

E-Mail: alimu@apps.ipb.ac.id
Submitted: MARET 2021

Accepted: JUNI 2021

\begin{abstract}
As management has the authority over the financial statements issued by the company, much of earnings management is trying to overhaul profits or what is called earnings engineering. One of the profit engineering techniques is income smoothing, which rules profits in order to reduce fluctuation. This study aims to analyze the effects of financial leverage and profitability on income smoothing. The object of this research is the IDX Quality 30 index (IDXQ30) Non-Bank for the 2015-2019 period. The data used is secondary data obtained from the companies' financial statements during the 2015-2019 period and literature studies. The method used in this research is binary logistic regression analysis with Debt to Asset Ratio (DAR), Debt to Equity Ratio (DER), Return on Assets (ROA), and Net Profit Margin (NPM) as independent variables and Eckel Index as dependent variable. The results showed that simultaneously DER, ROA, and NPM have a significant effect on income smoothing. Partially, DER and ROA have no effect on income smoothing, while NPM variable has a significant negative effect on income smoothing.
\end{abstract}

Keywords: financial leverage, income smoothing, profitability, binary logistic regression

\section{PENDAHULUAN}

Laba merupakan bagian penting bagi stakeholders perusahaan sehingga menjadi pusat perhatian yang memengaruhi keputusan investor dan kreditor (Priyanto 2017). Oleh sebab itu, perusahaan berupaya mengintervensi dan mempengaruhi informasi laporan keuangan dengan tujuan mempengaruhi stakeholders atau yang dikenal dengan manajemen laba.

Manajemen laba merupakan salah satu teknik rekayasa laba. Terdapat empat alasan yang membuat manajer melakukan rekayasa laba yaitu memenuhi target internal, memenuhi harapan pihak eksternal, memberikan perataan laba atau biasa disebut dengan income smoothing, agar memberikan laporan keuangan terlihat baik (window dressing) untuk kepentingan penawaran saham perdana publik atau pinjaman (Stice et al. 2007).

Manajemen diyakini sering termotivasi untuk merekayasa laba demi kepentingan perusahaan. Faktor-faktor yang mempengaruhi perataan laba di antaranya adalah ukuran perusahaan, profitabilitas, financial leverage, dan dividend payout ratio (Budiasih 2009). Penelitian ini lebih memfokuskan pada penggunaan pengungkit keuangan/ financial leverage dan profitabilitas.

Perusahaan-perusahaan terbuka yang memiliki profitabilitas tinggi, solvabilitas baik, dan pertumbuhan laba stabil dengan likuiditas transaksi yang baik terdapat pada indeks IDX Quality 30 (IDXQ30). IDXQ30 merupakan indeks yang terdiri dari 30 perusahaan

\section{JIMKES}

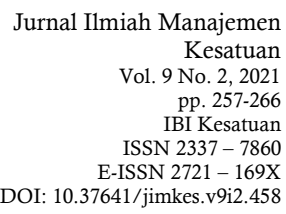


Financial Leverage and Profitability effect in IDXQ3 profit

\section{8}

yang diseleksi dengan melihat variabel kualitas fundamental seperti rasio return on equity (ROE), debt to equity (DER), dan earning variability. Karenanya, menarik untuk mengetahui, apakah kinerja perusahaan-perusahaan tersebut murni diperoleh tanpa melakukan praktik perataan laba. Penelitian ini tidak mengikutsertakan perbankan dengan pertimbangan perbankan memiliki karakteristik khusus menghimpun dana masyarakat menjadi dana pihak ketiga sehingga memiliki utang besar.

Beragam penelitian serupa menunjukkan hasil yang beragam. Wulandari dan Situmorang (2020) menyatakan bahwa profitabilitas berpengaruh terhadap perataan laba, sedangkan financial leverage tidak berpengaruh terhadap perataan laba pada perusahaan manufaktur yang terdaftar di BEI. Namun, Pradnyandari dan Putra Astika (2019) mengatakan bahwa financial leverage dan profitabilitas berpengaruh positif terhadap perataan laba pada sektor manufaktur di Bursa Efek Indonesia. Hasil berbeda ditemukan Dewi dan Suryanawa (2019), yang menyimpulkan bahwa leverage dan profitabilitas tidak berpengaruh pada praktik perataan laba pada perusahaan industri barang konsumsi. Berdasarkan uraian tersebut, rumusan masalah yang diajukan adalah (1) Bagaimana pengaruh pengungkit keuangan terhadap perataan laba pada Indeks IDX Quality 30 NonBank periode 2015-2019? (2) Bagaimana pengaruh profitabilitas terhadap perataan laba pada Indeks IDX Quality 30 Non-Bank periode 2015-2019? (3) Bagaimana pengaruh pengungkit keuangan dan profitabilitas secara simultan terhadap perataan laba pada Indeks IDX Quality 30 Non-Bank periode 2015-2019?

\section{Penelitian Terdahulu}

Fatmawati dan Djajanti (2015) melakukan penelitian berjudul "Pengaruh Ukuran Perusahaan, Profitabilitas dan Finansial Leverage terhadap Praktik Perataan Laba pada Perusahaan Manufaktur yang Terdaftar di Bursa Efek Indonesia". Variabel yang digunakan dalam penelitian ini adalah variabel dependen yaitu praktik perataan laba dan variabel independen yaitu ukuran perusahaan, profitabilitas, dan financial leverage. Alat analisis yang digunakan adalah metode regresi logistik biner. Hasil penelitian ini menunjukkan bahwa pengujian secara parsial ukuran perusahaan yang diproksikan oleh natural logarithm of total asset, proksi profitabilitas dengan Return on Assets (ROA) dan financial leverage diproksikan dengan Debt to Total Assets Ratio (DAR) secara individual berpengaruh signifikan terhadap praktik perataan laba. Secara simultan menggunakan uji omnibus juga mencapai kesimpulan yang sama.

Sementara Rifky et al. (2017) melakukan penelitian berjudul "Pengaruh Return on Assets, Net Profit Margin, dan Financial Leverage terhadap Praktik Perataan Laba (Studi Pada Perusahaan Manufaktur Sektor Barang Konsumsi di BEI Periode 2013-2015)". Variabel yang digunakan dalam penelitian ini adalah variabel dependen yaitu praktik perataan laba dan variabel independen yaitu return on asssets, net profit margin, dan finansial leverage. Penelitian tersebut menggunakan metode analisis regresi logistik. Hasil penelitian ini menunjukan bahwa secara simultan tidak terdapat pengaruh yang signifikan antara Return on Assets (ROA), Net Profit Margin (NPM), dan Financial Leverage (DER) terhadap Praktik Perataan Laba. Secara parsial Return on Assets (ROA), Net Profit Margin (NPM) dan Financial Leverage (DER) tidak berpengaruh signifikan terhadap pembiayaan murabahah. 
Kerangka Pemikirian

Kerangka pemikiran dalam penelitian ini adalah sebagai berikut:

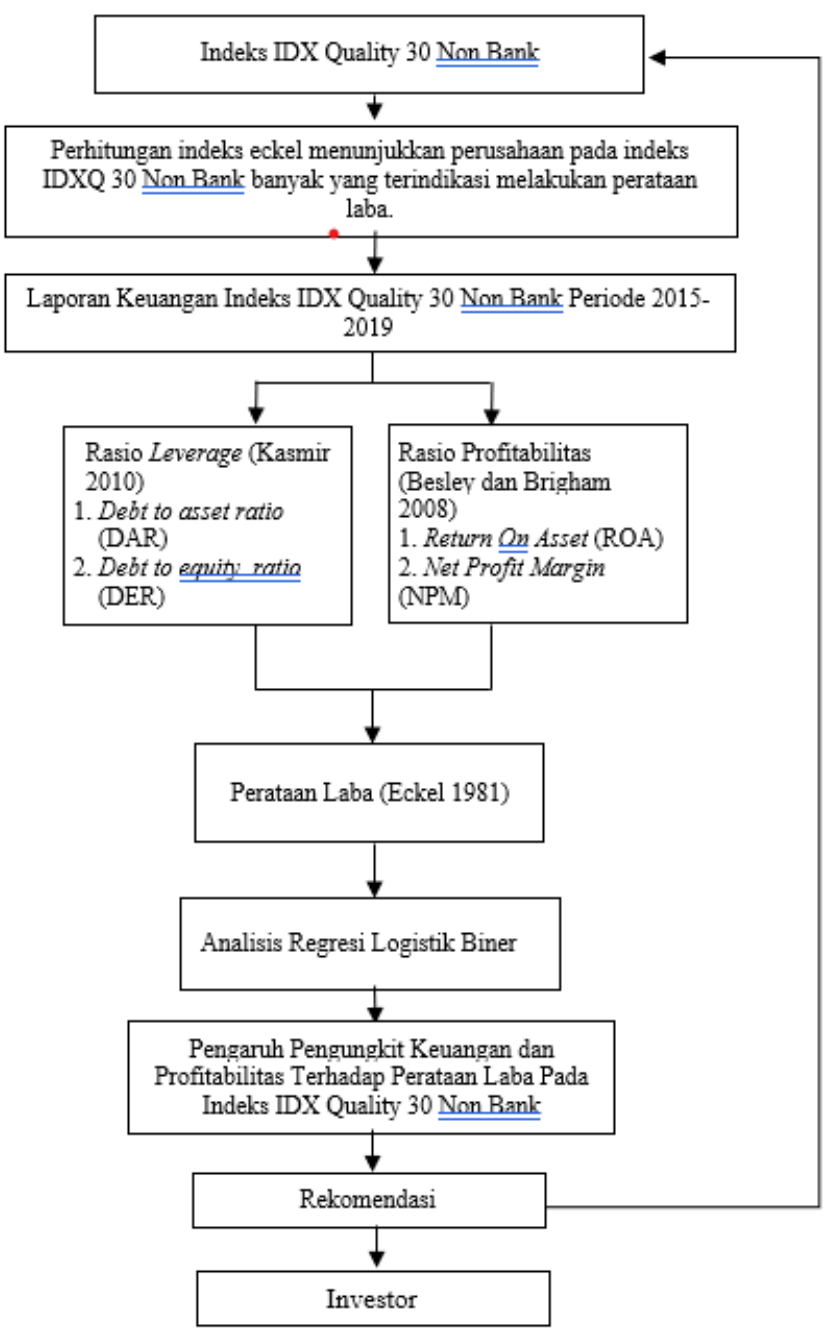

Gambar 1. Kerangka Pemikiran

\section{Hipotesis Penelitian}

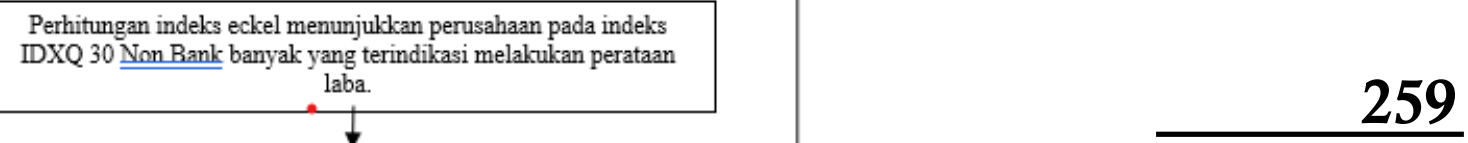

\section{Pengaruh Pengungkit Keuangan terhadap Perataan Laba}

Pengungkit Keuangan merupakan ukuran utang terhadap perusahaan, sehingga semakin besar pengungkit keuangan semakin besar pula rasio utang perusahaan. Semakin besar hutang, semakin besar pula motivasi manajemen untuk melakukan perataan laba guna menunjukkan kepada kreditor kinerja labanya yang stabil. "Rasio leverage digunakan untuk mengukur sejauh mana kemampuan perusahaan dapat membiayai kewajibannya jangka pendek maupun jangka panjang jika perusahaan dilikuidasi" (Kasmir 2010). Dalam penelitian ini DAR diukur dengan cara membagi total utang dengan total aset dan DER diukur dengan membagi total utang dengan ekuitas. Pernyataan DAR berpengaruh signifikan ini sejalan dengan penelitian yang dilakukan oleh Fatmawati dan Djajanti (2015) sedangkan DER berpengaruh signifikan selaras dengan hasil yang ditemukan Ramanuja dan Mertha (2015).

H1 : Debt to Assets Ratio (DAR) berpengaruh terhadap Perataan Laba.

H2 : Debt to Equity Ratio (DER) berpengaruh terhadap Perataan Laba.

\section{Pengaruh Profitabilitas terhadap Perataan Laba}

Profitabilitas merupakan kemampuan suatu perusahaan dalam menghasilkan laba. Menurut Besley dan Brigham (2008), profitabilitas adalah laba bersih dari sejumlah kebijakan dan keputusan. Rasio yang diperiksa sejauh ini memberikan beberapa informasi tentang cara perusahaan beroperasi, tetapi rasio profitabilitas menunjukkan efek gabungan dari manajemen likuiditas, manajemen aset dan manajemen hutang pada 
Financial Leverage and Profitability effect in IDXQ3 profit

260 hasil operasi. Bagaimanapun profitabilitas yang ada, dalam kondisi tertentu dapat mendorong manajemen meratakan laba guna mencegah variabilitas laba yang ekstrem. Dalam penelitian ini profitabilitas diukur dengan membagi laba bersih terhadap total aset atau return on asset (ROA) dan dengan membagi laba bersih terhadap penjualan atau net profit margin (NPM). Pernyataan ROA berpengaruh signifikan hal ini sejalan dengan penelitian yang dilakukan Kusumaningrostati dan Mutasowifin (2016). Sedangkan pernyataan NPM berpengaruh signifikan hal ini sejalan dengan penelitian yang dilakukan Mirwan dan Amin (2020).

H3 : Return on Asset (ROA) berpengaruh terhadap Perataan Laba.

H4 : Net Profit Margin (NPM) berpengaruh terhadap Perataan Laba.

\section{METODOLOGI PENELITIAN}

Lokasi penelitian ini dilakukan pada Indeks IDX Quality 30 Non Bank. Sedangkan untuk waktu penelitian dilakukan pada bulan Agustus 2020 sampai dengan Desember 2020. Metode pengambilan sampel yang digunakan dalam penelitian ini adalah purposive sampling. Teknik purposive sampling merupakan teknik pengambilan data dengan pertimbangan tertentu (Sugiyono 2011). Kriteria yang digunakan sebagai berikut:

1. Perusahaan dalam indeks IDX Quality 30 (indeks yang terdiri dari 30 perusahaan yang diseleksi secara substansi dengan melihat dari sisi variabel kualitas fundamental seperti rasio return on equity (ROE), debt to equity (DER), dan earning variability yang terdaftar di BEI.

2. Perusahaan tersebut merupakan perusahaan non bank karena perbankan memiliki karakteristik khusus menghimpun dana masyarakat menjadi dana pihak ketiga sehingga memiliki utang besar, yang jika dimasukkan dalam model penelitian menjadikan bias serta menjadi pencilan.

3. Perusahaan tersebut telah mempublikasikan laporan keuangan selama periode 2015-2019.

Berdasarkan populasi terdapat 30 perusahaan yang terdaftar pada indeks IDX Quality 30. Sebanyak 2 perusahaan tidak memenuhi kriteria karena laporan keuangan yang tidak lengkap dari tahun 2015 sampai 2019 dan sebanyak 7 perusahaan perbankan, sehingga diperoleh 21 sampel perusahaan.Jenis data yang digunakan dalam penelitian ini adalah data sekunder dan merupakan data kuantitatif. Sumber data yang digunakan dalam penelitian ini adalah data yang didapatkan dari laporan keuangan perusahaan yang dipublikasikan di IDX.

Identifikasi Variabel

1. Variabel independent (bebas) yaitu pengungkit keuangan yang diproksikan dengan rasio solvabilitas dengan indikator debt to asset ratio (DAR) dan debt to equity ratio (DER) serta profitabilitas yang diproksikan dengan rasio profitabilitas dengan indikator return on assets (ROA) dan net profit margin (NPM).

2. Variabel dependent (terikat) yaitu perataan laba.

\section{Metode Analisis Data}

Metode pengolahan data yang digunakan dalam penelitian ini adalah dengan analisis kuantitatif untuk melihat ada tidaknya pengaruh debt to assets ratio (DAR), debt to equity ratio (DER), return on assets (ROA), dan net profit margin (NPM) terhadap perataan laba. Data yang diperoleh dari laporan keuangan diolah dengan menggunakan Microsoft Excel 2016 untuk mendapatkan nilai rasio yang diinginkan. Alat analisis yang digunakan dalam penelitian ini untuk mengetahui pengaruh pengungkit keuangan dan profitabilitas terhadap perataan laba pada Indeks IDX Quality 30 Non Bank periode 2015-2019 dengan jumlah objek 21 perusahaan adalah analisis regresi logistik biner dengan menggunakan aplikasi SPSS versi 26. 
HASIL DAN PEMBAHASAN

Tahapan pertama yang dilakukan dalam penelitian ini adalah melakukan perhitungan Indeks Eckel untuk mengetahui status perusaaan menjadi perusahaan perata laba dan perusahaan bukan perata laba. Data tersebut terdapat pada Tabel 1.

Tabel 1 Perusahaan Perata Laba

\begin{tabular}{rlllll}
\hline No & \multicolumn{1}{c}{2015} & 2016 & 2017 & \multicolumn{1}{c}{2018} & 2019 \\
\hline 1 & CPIN & CPIN & ACES & DMAS & ACES \\
2 & DMAS & DMAS & CPIN & LINK & CPIN \\
3 & HMSP & HMSP & ICBP & MIKA & INTP \\
4 & ICBP & ICBP & INTP & MNCN & KLBF \\
5 & INTP & INTP & MIKA & PTBA & LINK \\
6 & KLBF & MIKA & MNCN & PWON & MIKA \\
7 & MIKA & MNCN & PTBA & SCMA & PTBA \\
8 & MNCN & MYOR & PWON & TLKM & PWON \\
9 & MYOR & PTBA & RALS & UNTR & RALS \\
10 & PTBA & PWON & SCMA & & SCMA \\
11 & PWON & SCMA & TLKM & & UNVR \\
12 & SCMA & SMSM & & & \\
13 & SIDO & UNTR & & & \\
14 & UNTR & UNVR & & & \\
15 & UNVR & & & & \\
\hline
\end{tabular}

Sumber: Laporan keuangan perusahaan IDXQ 30 dari BEI (2020), diolah

Pada tabel 1 dapat dilihat jumlah perusahaan perata laba pada perusahaan IDX Quality 30 Non Bank Periode 2015-2019. Pada 2015 terdapat 15 perusahaan perata laba. Pada 2016 jumlah perusahaan yang melakukan praktik perataan laba menurun dibandingkan tahn sebelumnya yang sebanyak 14 perusahaan. Tahun 2017 pun jumlah perusahaan yang malakukan perataan laba menurun dari tahun sebelumnya menjadi 11 perusahaan. Pada Tahun 2018 mengalami penurunan dari tahun sebelumnya menjadi hanya 9 perusahaan melakukan perataan laba. Namun pada 2019 kembali mengalami peningkatan dengan 11 perusahaan melakukan perataan laba.

Berdasarkan data di atas, diketahui bahwa tahun dengan perusahaan perata laba terbanyak di IDX Quality 30 ada di tahun tahun 2015 dibandingkan dengan tahun 2016, 2017, 2018, dan 2019. Biasanya perusahaan akan melakukan praktik perataan laba pada tahun-tahun sulit. Perekonomian Indonesia selama periode tahun 2015 memang dihadapkan pada rangkaian kejutan eksternal dalam perekonomian global, yang berdampak ke Indonesia baik melalui jalur keuangan maupun perdagangan disertai dengan kemerosotan harga komoditas dan ketidakpastian kecepatan dan besarnya kenaikan suku bunga di Amerika Serikat yang berdampak kepada perekonomian di Indonesia (BI 2016). Data Badan Pusat Statistik mencatat, ekonomi Indonesia pada 2015 tumbuh 4,79 persen. Angka ini lebih rendah jika dibandingkan dengan tahun 2014 yang tumbuh sebesar 5,02\% (BPS 2016).

Kondisi perekonomian tersebut berdampak pada kinerja berbagai sektor perusahaan di Indonesia. Bagi manajemen, perataan laba untuk menjaga kestabilan pendapatan dianggap hal lumrah untuk dilakukan disaat perekonomian sedang melemah seperti pada 2015 , sehingga laba terlihat tetap menarik pada tahun-tahun dengan ketidakpastian ekonomi. Langkah selanjutnya dalam penelitian ini adalah pengujian regresi logistik antara variabel dependen dan variabel independen pada 60 sampel yang berstatus sebagai perusahaan perata laba. Analisis regresi logistik biner dilakukan dalam beberapa evaluasi, sebagai berikut:
Financial Leverage and Profitability effect in IDXQ3 profit 
Financial Leverage and Profitability effect in IDXQ3 profit

\section{2}

1. Uji Signifikansi

a. Omnibus tests of Model Coefficients (Pengujian Simultan)

Omnibus test of Model Coefficients (Pengujian Simultan/f-test) digunakan untuk mengetahui bagaimanakah pengaruh dari seluruh variable independen secara simultan atau bersama-sama. Hasil Omnibus tests of Model Coefficients (pengujian simultan) ditunjukkan pada tabel berikut:

Tabel 2 Hasil Pengujian Simultan

DAR terdapat dalam model

\begin{tabular}{ll|r|r|r} 
& & Chi-square & df & \multicolumn{1}{c}{ Sig. } \\
\hline Step 1 & Step & 6.785 & 4 & .148 \\
\cline { 2 - 6 } & Block & 6.785 & 4 & .148 \\
\cline { 2 - 5 } & Model & 6.785 & 4 & .148 \\
\hline
\end{tabular}

DAR dibuang dalam model

\begin{tabular}{llr|r|r}
\multicolumn{2}{c}{ Chi-square } & df & Sig. \\
\hline Step 1 & Step & 6.704 & 3 & .082 \\
\cline { 2 - 5 } & Block & 6.704 & 3 & .082 \\
\cline { 2 - 5 } & Model & 6.704 & 3 & .082 \\
\hline
\end{tabular}

Sumber: Data diolah (2020)

Berdasarkan tabel 2, hasil sebelum DAR dikeluarkan menunjukkan nilai sig. pada model sebesar 0,148 di mana nilai tersebut di atas 0,10 yang artinya tidak ada pengaruh bersama-sama DAR, DER, ROA, dan NPM terhadap perataan laba. Namun setelah DAR dikeluarkan, nilai sig. pada model sebesar 0,082 di mana nilai tersebut di bawah 0,10 yang berarti terdapat pengaruh bersama-sama DER, ROA, dan NPM terhadap perataan laba. Maka model tanpa DAR lebih baik dibandingkan dengan DAR.

\section{b. Model Summary (Koefisien Determinan)}

Model summary dalam regresi logistik sama dengan pengujian $\mathrm{R}^{2}$ yang menunjukkan apakah model yang dipakai dalam regresi cocok untuk dilanjutkan. Jika nilainya 1 , maka regresi menjelaskan variabel $Y$ secara sempurna, sebaliknya apabila $R^{2}$ nilainya 0 , maka model tersebut tidak dapat menjelaskan variabel Y (Gujarati 2010). Hasil dari model summary dapat ditunjukkan dalam tabel sebagai berikut:

\begin{tabular}{rr|rrr}
\multicolumn{9}{c}{ Tabel 3 Hasil Model Summary } \\
Step & -2 Log likelihood & $\begin{array}{c}\text { Cox \& Snell R } \\
\text { Square }\end{array}$ & $\begin{array}{c}\text { Nagelkerke R } \\
\text { Square }\end{array}$ \\
\hline 1 & $136.707^{\mathrm{a}}$ & .062 & .083 \\
\hline
\end{tabular}

Sumber: Data diolah (2020)

Berdasarkan tabel 3 model logistik pada hasil omnibus menunjukkan bahwa model logistik berpengaruh terhadap perataan laba. Seberapa baik model logistik mampu menjelaskan perataan laba dapat dilihat dari nilai Negelkerke RSquare. Nilai Negelkerke Rsquare sebesar $8,3 \%$ yang artinya kombinasi variabel independent yaitu pengungkit keuangan dan profitabilitas mampu menjelaskan keragaman perataan laba sebesar 8,30\% dan sisanya $(100 \%-8,30 \%=91,70 \%)$ dijelaskan oleh variabel lain yang tidak ada dalam model.

2. Uji Kebaikan/Kelayakan Model

a. Hosmer and Lemeshow Test

Pengujian ini untuk mengetahui apakah persamaan yang diperoleh sesuai untuk menjelaskan hubungan antara variabel dependen dan independen. Berikut hasil uji Hosmer and Lemeshow Test: 
Tabel 4 Hasil uji Hosmer and Lemeshow Test

\begin{tabular}{rrrrr} 
Step & Chi-square & df & Sig. \\
\hline 1 & 10.833 & 8 & .211
\end{tabular}

Sumber: Data diolah (2020)

Berdasarkan tabel 4, hasil pengujian Hosmer and Lemeshow menunjukkan bahwa nilai Sig. pada model menunjukkan nilai sebesar $0,211>0,10$ yang artinya terima atau model logistik layak untuk digunakan.

b. Classification Table

Berikut hasil classification table:

Tabel 5 Hasil Classification Table

\begin{tabular}{|c|c|c|c|c|c|}
\hline & \multirow{3}{*}{\multicolumn{2}{|c|}{ Observed }} & \multicolumn{3}{|c|}{ Predicted } \\
\hline & & & \multicolumn{2}{|c|}{ Income Smoothing } & \multirow[b]{2}{*}{$\begin{array}{c}\text { Percentage } \\
\text { Correct }\end{array}$} \\
\hline & & & Tidak & $a^{Y}$ & \\
\hline \multirow[t]{3}{*}{ Step 1} & Income & Tidak & 12 & 33 & 26.7 \\
\hline & Smoothing & $\mathrm{Ya}$ & 8 & 52 & 86.7 \\
\hline & Overall Perc & & & & 61.0 \\
\hline
\end{tabular}

Sumber: Data diolah (2020)

Tabel 5 di atas melihat seberapa baik model logistik dalam memprediksi perataan laba. Jika dilihat pada overall percentage yaitu sebesar $61,00 \%$ yang menunjukkan bahwa model logistic mampu memprediksi dengan benar sebesar $61,00 \%$. Hal ini tentu menunjukkan model logistic cukup baik.

3. Uji Hipotesis

Uji hipotesis dilakukan dengan menggunakan uji parsial atau uji t untuk menunjukkan pengaruh variabel independen secara parsial terhadap variabel dependen dengan anggapan variabel independen lainnya tetap (Ghozali dan Ratmono 2017). Hasil pengujian parsial sebagai berikut:

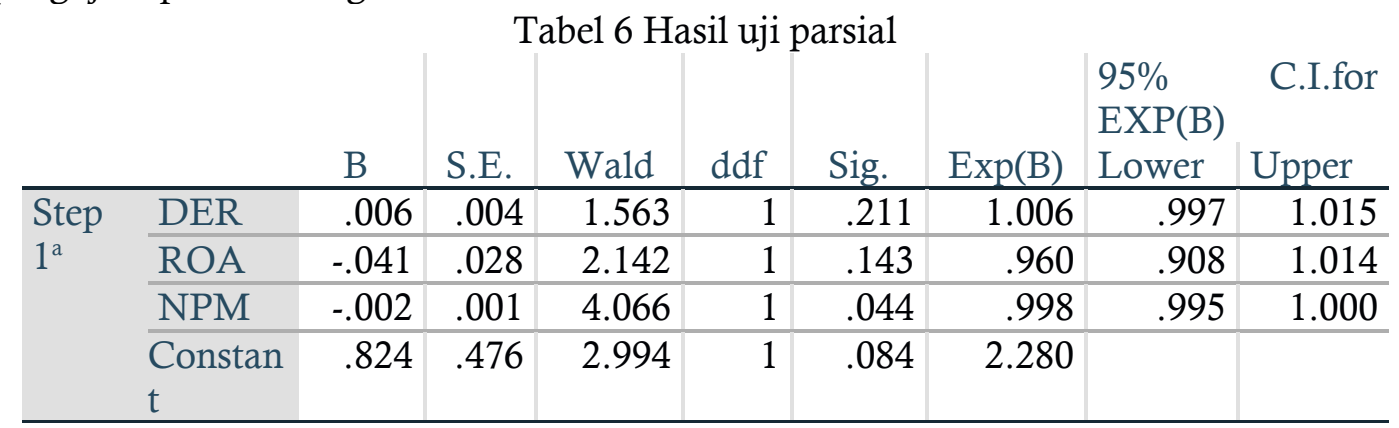

Sumber: Data diolah (2020)

Berdasarkan hasil pengujian tersebut dapat dirumuskan persamaan model regresi logistik sebagai berikut:

$$
\text { IS }=0.824+0.006 \text { DER }-0.41 \text { ROA }-0.002 \mathrm{NPM}+\mathrm{e}
$$

Berikut pemaparan hasil uji hipotesis yang telah dilakukan berdasarkan tabel 6 .

a) Pengaruh Debt to Equity Ratio (DER) terhadap Perataan Laba

Hasil penelitian ini menunjukkan bahwa variabel DER menghasilkan nilai Wald Statistic atau uji parsial sebesar 1,563 dan nilai prob sebesar 0,211. Hal tersebut menunjukkan nilai prob lebih besar dari alpha sebesar $10 \%$ yang menunjukkan terima $\mathrm{H}_{0}$ atau variabel DER tidak berpengaruh terhadap perataan laba. Hipotesis kedua yang diajukan oleh peneliti ditolak atau tidak dapat diterima. Hal ini dikarenakan perusahaan yang berada pada posisi terancam melakukan perjanjian utang cenderung melakukan manajemen laba menggunakan income smoothing. Penelitian ini sejalan dengan dengan Rifky et al. (2017), Anwar dan Chandra (2017), Utari et al. (2017), Kusumaningrostati dan Mutasowifin (2016) yang membuktikan bahwa debt to equity ratio (DER) tidak
Financial Leverage and Profitability effect in IDXQ3 profit 
Financial Leverage and Profitability effect in IDXQ3 profit

\section{4}

berpengaruh signifikan terhadap praktik perataan laba. Namun berbeda dengan penelitian yang dilakukan Ramanuja dan Mertha M (2015) yang membuktikan bahwa debt to equity ratio (DER) memiliki pengaruh yang signifikan dengan arah positif terhadap praktik perataan laba.

b) Pengaruh Return on Assets (ROA) terhadap Perataan Laba

Hasil penelitian ini menunjukkan bahwa variabel ROA menghasilkan nilai Wald Statistic sebesar 2,142 dan nilai prob sebesar 0,143 . Hal tersebut menunjukkan nilai prob lebih besar dari alpha sebesar $10 \%$ yang menunjukkan terima $\mathrm{H}_{0}$ atau variabel $\mathrm{ROA}$ tidak berpengaruh terhadap perataan laba. Hipotesis ketiga yang diajukan oleh peneliti tidak dapat diterima. Hal ini dikarenakan objek pada penelitian ini adalah IDXQ 30 non bank yang merupakan perusahaan dengan profitabilitas tinggi. Akibatnya, manajemen perusahaan dengan profit tinggi enggan untuk melakukan praktik perataan laba. Hal ini dikarenakan perusahaan akan menjadi perhatian publik dan tentunya berisiko terhadap kredibilitas perusahaan yang masih melakukan perataan laba. Maka ROA masih dalam posisi yang harus dipertimbangkan baik oleh perusahaan. Penelitian ini konsisten dengan Ernayani et al. (2020), Rifky et al. (2017), Anwar dan Chandra (2017), dan Fitriani (2018) bahwa profitabilitas tidak berpengaruh terhadap perataan laba. Namun hasil yang berlawanan ditunjukkan dengan penelitian yang dilakukan oleh Alexandri dan Anjani (2014) yang membuktikan bahwa profitabilitas (ROA) berpengaruh signifikan terhadap variabel perataan laba.

c) Pengaruh Net Profit Margin (NPM) terhadap Perataan Laba

Hasil penelitian ini menunjukkan bahwa laba atau jika NPM naik maka peluang terjadinya income smoothing variabel NPM menghasilkan nilai Wald Statistic sebesar 4,066 dan nilai prob sebesar 0,044 . Hal tersebut menunjukkan nilai prob lebih kecil dari alpha sebesar $10 \%$ yang menunjukkan tolak $\mathrm{H}_{0}$ atau variabel NPM berpengaruh terhadap perataan laba. Nilai odd ratio sebesar 0,998 menunjukkan bahwa jika NPM naik 1\% maka peluang perataan laba untuk terjadi sebesar 0,998 kalinya dibandingkan tidak terjadinya perataan laba. Dengan demikian, hipotesis keempat yang diajukan dapat diterima. Hal ini dikarenakan perusahaan yang memiliki profit margin rendah kurang diminati oleh investor. Alasan lain, net profit margin berhubungan langsung dengan objek perataan laba yaitu laba setelah pajak. Investor cenderung melihat laba setelah pajak untuk pengambilan keputusan investasi. Alasan tersebut yang memacu manajemen laba untuk melakukan perataan laba agar terlihat stabil. Dalam interpretasinya NPM dapat menunjukkan seberapa baik perusahaan mengubah penjualannya menjadi laba. Dengan kata lain, persentase yang dihitung dengan persamaan margin laba bersih adalah persentase pendapatan yang merupakan laba yang disimpan perusahaan. Selain itu, berpengaruhnya net profit margin terhadap praktik perataan laba dikarenakan perusahaan belum mampu menghasilkan kinerja yang baik dalam hal kegiatan penjualannya, sehingga manajemen diduga melakukan praktik perataan laba supaya kinerja perusahaan dapat terlihat baik di mata investor (Sholikhah dan Worokinasih 2018). Penelitian ini konsisten dengan Herlina et al. (2017), Primatama (2015), Mirwan dan Amin (2020), dan (Sholikhah dan Worokinasih 2018) bahwa net profit margin berpengaruh signifikan terhadap perataan laba. Namun hasil yang berlawanan ditunjukkan dengan penelitian yang dilakukan oleh Kurniawati et al. (2019) dan Rifky et al. (2017) tidak berpengaruh signifikan terhadap perataan laba.

\section{KESIMPULAN DAN SARAN \\ Kesimpulan}

Berdasarkan tujuan penelitian dan hasil pembahasan yang dapat disimpulkan hal-hal berikut:

1. Variabel pengungkit keuangan yang diproksikan dengan DER tidak berpengaruh terhadap perataan laba.

2. Variabel profitabilitas yang diproksikan dengan ROA tidak berpengaruh terhadap perataan laba. Sedangkan variabel profitabilitas yang diproksikan dengan NPM memiliki pengaruh negatif signfikan terhadap perataan laba. 
3. Variabel pengungkit keuangan yang diproksikan dengan DER serta variabel profitabilitas yang diproksikan dengan ROA dan NPM berpengaruh secara simultan terhadap perataan laba.

\section{DAFTAR PUSTAKA}

[1] Alexandri M, Anjani W. 2014. Income Smoothing: Impact Factors, Evidence In Indonesia. International Journal of Small Business and Entrepreneurship Research Vol.3,No.1,pp.21-27,January 2014. www.eajournals.org.

[2] Anwar A, Chandra T. 2017. The Analysis Of Factors Affect Income Smoothing On Miscellaneous Industry Companies Listed On Indonesia Stock Exchange. Jurnal Benefita 2(3). ISSN: 2477-7862.

[3] [BEI] Bursa Efek Indonesia (ID). 2020. Laporan Keuangan Tahunan [Internet]. [diunduh 2020 Sep 12]. Tersedia pada: www.idx.co.id

[4] Beidelman, C.R. 1973. Income Smoothing: The Role of Management. The Accounting Review.

[5] [BI] Bank Indonesia (ID). 2016. Laporan Perekonomian Indonesia Tahun 2015 [internet]. [diunduh 2020 Desember 02]. Tersedia pada: https://www.bi.go.id/id/publikasi/laporan-

tahunan/perekonomian/Pages/LPI_2015.aspx.

[6] [BPS] Badan Pusat Statistik [ID]. 2016. Ekonomi Indonesia Triwulan IV 2015 tumbuh 5,04 persen tertinggi selama tahun 2015 [internet]. [diunduh 2020 Desember 02]. Tersedia pada: https://www.bps.go.id/pressrelease/2016/02/05/1267/ekonomi-indonesiatriwulan-iv-2015-tumbuh-5-04-persen-tertinggi-selama-tahun2015.html\#: :text=Ekonomi\%20Indonesia\%20tahun\%202015\%20tumbuh,oleh\% 20Komponen\%20Pengeluaran\%20Konsumsi\%20Pemerintah.

[7] Besley S, Brigham EF. 2008. Essentials of Managerial Finance, Fourteenth Edition 14. Mason(US): Thomson Higher Education.

[8] Budiasih I. (2009). "Faktor yang Mempengaruhi Praktik Perataan Laba". Jurnal Akuntansi Bisnis Vol. 4 No. 1 p44-50. Fakultas Ekonomi Jurusan Akuntansi Universitas Udayana.

[9] Eckel N. 1981. Smoothing Hypothesis Revisited. Abacus. 17(1):28-40.

[10] Ernayani R, Herianingrum S, Widiastuti T et al. 2020. Factors influencing income smoothing practice in the oil and natural gas mining companies during 2012-2016 period. Humanities and Social Sciences Reviews.

[11] Fatmawati, Djajanti A. 2015. Pengaruh Ukuran Perusahaan , Profitabilitas dan Financial Leverage terhadap Praktik Perataan Laba pada Perusahaan Manufaktur yang Terdaftar di Bursa Efek Indonesia. Kelola Vol 2 No3 edisi September 2015. ISSN: 2337-5965.

[12] Fitriani A. 2018. Pengaruh Profitabilitas, Ukuran Perusahaan, dan Financial Leverage terhadap Praktik Perataan Laba (Income Smoothing) pada Perusahaan Farmasi yang Terdaftar di Bursa Efek Indonesia Periode 2011-2015. Jurnal Samudra Ekonomi dan Bisnis. 9(1). doi:10.33059/jseb.v9i1.461.

[13] Ghozali I, Ratmono D. 2016. Aplikasi Analisis Multivariete dengan Program IBM SPSS 23 Edisi 8. Semarang(ID): Universitas Diponegoro.

[14] Ghozali I, Ratmono D. 2017. Analisis Multivariat dan Ekonometrika Teori Konsep, dan Aplikasi dengan Eviews 10 Edisi 2. Semarang(ID): Universitas Diponegoro.

[15] Gujarati DN. 2010. Ekonometrika Dasar. Zain dan Sumarno [penerjemah].Jakarta (ID): LPFE-Usakti.

[16] Herlina S, Zulbahridar Z, Yasni H. 2017. Pengaruh Ukuran Perusahaan, Financial Leverage, Net Profit Margin Dan Struktur Kepemilikan Terhadap Tindakan Perataan Laba Padaperusahaan Manufaktur Yang Terdaftar Di Beiperiode 20112014. Jurnal Online Mahasiswa Fakultas Ekonomi Universitas Riau. ISSN: 23556854.
Financial Leverage and Profitability effect in IDXQ3 profit 
Financial Leverage and Profitability effect in IDXQ3 profit
[17] Kasmir. 2010. Pengantar Manajemen Keuangan. Jakarta(ID): PT Kencana.

[18] Kontan. 2018. Surya Citra Media (SCMA) punya banyak peluang di tengah tantangan [internet]. [diunduh 2020 November 18]. Tersedia pada: https://investasi.kontan.co.id/news/surya-citra-media-scma-punya-banyakpeluang-di-tengah-tantangan

[19] Kurniawati Y, Kananlua P, Susetyo S. 2019. Pengaruh Return On Asset, Debt To Equity Ratio, Net Profit Margin Terhadap Income Smoothing Dengan Variabel Moderasi Proporsi Wanita Di Dalam Dewan Direksi (Studi Kasus Pada Perusahaan Manufaktur Yang Terdaftar Di Bursa Efek Indonesia Pada Tahun 2013-2015). Managament Insight: Jurnal Ilmiah Manajemen 12(2). doi: 10.33369/insight.12.2.89-100.

[20] Kusumaningrostati A, Mutasowifin A. 2016. Analisis Pengaruh Faktor-Faktor terhadap Income Smoothing dengan Gender sebagai Variabel Moderator pada Emiten Perbankan.

[21] Mirwan D, Amin M. 2020. Pengaruh Financial Leverage, Profitabilitas, Net Profit Margin, dan Ukuran Perusahaan Terhadap Praktik Perataan Laba. Akuntabilitas 14(2). doi: 10.29259/ja.v14i2.10982.

[22] Pradnyandari A, Putra Astika. 2019. Pengaruh Ukuran Perusahaan, Nilai Saham, Financial Leverage, Profitabilitas Pada Tindakan Perataan Laba di Sektor Manufaktur. E-Jurnal Akuntansi. doi:10.24843/eja.2019.v27.i01.p06.

[23] Primatama W. 2015. Pengaruh Company Size, Return On Asset, Net Profit Margin, Financial Leverage dan Operating Profit Margin Terhadap Praktik Income Smoothing. Journal of Banking and Finance 5(1). ISSN: 03784266.

[24] Priyanto AA. 2017. Analisis Pengaruh Profitabilitas, Financial Leverage dan Ukuran Perusahaan Terhadap Perataan Laba. Jurnal Mandiri. 1(1). doi:10.33753/mandiri.v1i1.8.

[25] Rifky M, Wahjoe Hapsari D, Julliana Dillak V. 2017. Pengaruh Return On Assets, Net Profit Margin, dan Financial Leverage Terhadap Praktik Perataan Laba (Studi pada Perusahaan Manufaktur Sektor Barang Konsumsi di BEI Periode 2013-2015). e-Proceeding of Management 4(1).

[26] Sartono, A.R. 2010. Manajemen Keuangan: Teori dan Aplikasi. Edisi Keempat. Yogyakarta (ID): BPFE.

[27] Sholikhah RA, Worokinasih S. Pengaruh Return On Asset, Return On Equity, Dan Net Profit Margin Terhadap Praktik Perataan Laba (Income Smoothing) (Studi Pada Perusahaan Sektor Jasa Infrastruktur, Utilitas, Dan Transportasi Yang Terdaftar Di Bursa Efek Indonesia Periode 2014 - 2016). Jurnal Administrasi Bisnis (JAB) Vol 60 No 2 Juli 2018. administrasibisnis.studentjournal.ub.ac.id

[28] Stice E.K. Stice J.D. dan Skousen K.F. 2007. Intermediate Accounting 16th Edition. South Western(US): Thomson.

[29] Sugiyono. 2011. Metode Penelitian Kuantitatif Kualitatif dan R\&D. Bandung(ID): Alfabeta.

[30] Utari R, Gustini E, Tripermata L. 2017. Pengaruh Profitabilitas, Financial Leverage, dan Dividend Payout Ratio Terhadap Perataan Laba Pada Perusahaan Manufaktur yang Terdaftar di BEI Tahun 2015. Jurnal Ilmiah Ekonomi Global Masa Kini Vol 8 No 02 Juli 2017. ISSN: 2089-6018.

[31] Ramanuja IGV, Mertha M. 2015. Pengaruh Varian Nilai Saham, Kepemilikan Publik, Der Dan Profitabilitas, Pada Perataan Laba. E-Jurnal Akuntansi 10(2). ISSN: 2302-8556.

[32] Wulandari Z, Situmorang IR. 2020. Pengaruh Profitabilitas, Ukuran Perusahaan Dan Financial Leverage Terhadap Perataan Laba (Studi Pada Perusahaan Manufaktur yang Terdaftar di BEI Tahun 2014-2018). Jurnal Akuntansi Bisnis EkaPrasetya.http://www.jurnal.ekaprasetya.ac.id/index.php/ABEP/article/view/52 